УдК 614.253.5:616.00,

DOI 10.11603/2411-1597.2021.3.12429

\title{
РОЛЬ ПАТОЛОГЇ̈ У СИСТЕМІ МЕДСЕСТРИНСЬКОЇ ОСВІТИ
}

\author{
Н. В. Ройко, Б. М. Филенко, І. І. Старченко, С. А. Проскурня
}

Полтавський державний медичний університет

\begin{abstract}
Реформа медсестринської справи вимагає великого числа фахівців нової формації і, отже, підвищення рівня їх освіти. Введення багаторівневої системи навчання медичних сестер дає можливість більш повної та конкретної підготовки фахівців для практичної охорони здоров’я. Концепція безперервної багаторівневої вищої медичної освіти реалізується шляхом викладання дисципліни «Патологія» від вивчення типових форм патології на фундаментальному рівні до аналізу конкретних, модельних ситуацій (синдромів і хвороб) на етапі клінічної підготовки.
\end{abstract}

\section{THE ROLE OF PATHOLOGY IN THE NURSING EDUCATION SYSTEM}

\section{N. V. Roiko, B. M. Filenko, I. I. Starchenko, S. A. Proskurnia \\ Poltava State Medical University}

\begin{abstract}
Reform of nursing services for a large number of new education and education, hence the advancement of education. The introduction of a bagator system for the education of medical nurses gives the possibility of more and more specific preparation of physicians for the practical protection of health. The concept of noninterruption-free supplemental medical education is implemented through the path of the week of the discipline "Pathology" from the development of typical forms of pathology on a fundamental basis to the analysis of specific, ready-made situations (syndromes).
\end{abstract}

Вступ. 3 розвитком медичної науки і практики постійно розвивається і збільшується роль медсестри, значення їі діяльності, що також вимагає нових форм організації її навчання на вищому рівні $з$ метою отримання досить глибоких і багатосторонніх знань. Нова концепція розвитку охорони здоров'я передбачає зміну ролі медсестринського персоналу в лікувально-профілактичних установах. Це спонукає до постійного реформування медичної освіти, в тому числі й першого (бакалаврського) рівня, у зв'язку з необхідністю забезпечення великою кількістю фахівців нової формації i, отже, підвищення рівня їх освіти [1]. Введення багаторівневої системи навчання медичних сестер дає можливість більш повної та конкретної підготовки фахівців для практичної охорони здоров'я.

Концепція безперервної багаторівневої вищої медичної освіти реалізується шляхом викладання дисципліни «Патологія», що полягає не лише у вивченні типових патологічних процесів та найпоширеніших захворювань на фундаментальному рівні, а й сприяє розвитку аналітичних вмінь з розв'язанням конкретних, модельних ситуацій (синдромів і хвороб) на етапі клінічної підготовки [2]. Підвищення ефективності формування особистості майбутнього фахівця здійснюється не шляхом пасивного засвоєння знань із застосуванням повного комплексу технічних і наочних дидактичних засобів [3], а шляхом вирішення здобувачами освіти різного роду проблемних, ситуаційних завдань, при високому теоретичному рівні теми, що вивчається.

Основна частина. Патологія - наука, яка вивчає структурні, біохімічні, функціональні зміни клітин, тканин і органів при патологічних процесах і станах, а також закономірності виникнення і розвитку окремих хвороб. Патологія $\epsilon$ основою всієї медицини, яка об'єднує базові науки з клінічною медициною; пояснює причини розвитку проявів хвороб (симптомів), виявлених у пацієнтів за допомогою діагностичних методів. Патологія узагальнює в собі патофізіологію та патоморфологію [4].

Патологія складається з двох розділів: загальної та спеціальної патології. При цьому існує нерозривний зв'язок і взаємозумовленість як загальнопатологіч-

(c) Н. В. Ройко, Б. М. Филенко, І. І. Старченко, С. А. Проскурня, 2021 
них процесів у розвитку захворювань, так і патофізіологічних та патоморфологічних змін в органах і тканинах, які формуються в процесі становлення, розвитку і наслідків хвороби, що підкреслює єдність структури і функції. Вивчення основ патології здобувачами освіти зі спеціальності «Медсестринство» має значення для формування їх клінічного мислення, оскільки кожний медичний працівник повинен мати чіткі критерії здоров'я та хвороби.

Системне викладання медичних дисциплін, у тому числі й основ патології, сприяє реалізації двох найважливіших педагогічних принципів: інтеграції різних ступенів навчання, а також наступності різних етапів підготовки фахівців у закладах медичної освіти, про що свідчить велика кількість публікацій [5-8]. Особливістю патології, як інтегративної науки, $\epsilon$ зв'язок основоположних медико-біологічних дисциплін (анатомії, нормальної фізіології, біохімії, біофізики та ін.) з клінічними дисциплінами [9].

Патологія - міст між клінічними і базисними теоретичними освітніми дисциплінами. Ї̈̈ інтегративним завданням $є$ формування медичного (клінічного) мислення. Завдяки патології осягаються внутрішня логіка, взаємозв'язок і біологічне значення процесів, що лежать в основі патології. У цьому полягає важливе значення основ патології в системі сестринської медичної освіти.

Необхідною умовою вдосконалення та оптимізації навчального процесу на кафедрі патологічної анатомії з секційним курсом $є$ нові технології лекційного курсу з патології. Розробка навчальних посібників з урахуванням новітніх даних патології диктується тим, що сучасні вузівські підручники з патоморфології і патофізіології в основному відображають високий науковий рівень інформації, але й вони потребують додаткової і більш сучасної інформації дидактичного характеру, в системному підході до тем і до встановлення взаємозв'язку між окремими темами.

Важливі методологічні аспекти виявляються і при розгляді взаємозв'язку патології з клінічними дисциплінами. Стирання меж патофізіології та патоморфології, проникнення в них ідей і методів біохімії, біофізики - з одного боку та процес активного використання і модифікації ідей та знань загально патологічних процесів і методів у клініці - з іншого становлять особливий інтерес у плані викладання, оскільки це дає можливість поглянути на проблеми патології з точки зору цілісного організму в його вищих проявах. Показ цих реальних протиріч у розвитку знань здобувача освіти надзвичайно важливий для правильного формування діалектико-матеріалістичного світогляду в нового покоління медичних сестер і підвищення якості навчання.

Наступність патології в системі медичних дисциплін має велике значення, оскільки вона знаходиться на стику біологічних і медичних наук. Узгодження навчальних цілей всіх кафедр університету, в тому числі патології як базового навчального предмета для клінічних дисциплін, лежить в основі наступності, координації та органічної інтеграції з іншими навчальними дисциплінами.

Висновки. 3 практично неосяжного спектра інформації необхідно виділити проблеми, вкрай необхідні медсестрі-менеджеру. Уточнення програм і пунктів дотику патології та суміжних дисциплін повинно стати предметом роботи методичних комісій університету. Прогрес у цьому напрямку сприятиме як розвитку науки, так і більш якісному вихованню та навчанню медичних сестер.

\section{СПИСОК ЛІТЕРАТУРИ}

1. Білаш С. М. Формування клінічного мислення при вивченні дисципліни «Анатомія людини з фізіологією» у студентів спеціальності «Медсестринство», які здобули базову загальну середню освіту / С. М. Білаш, Я. О. Олійніченко, М. М. Коптев // Сучасна медична освіта: методологія, теорія, практика : матеріали Всеукр. навч.-наук. конф. з міжнар. участю, м. Полтава, 19 березня 2020 р. Полтава, 2020. - С. 23-24.

2. Бабенко В. І. Навчально-методичне та матеріальнотехнічне забезпечення освітнього процесу при вивченні патоморфології / В. І. Бабенко, С. М. Совгиря, Н. І. Винник

[та ін.] // Актуальні питання вищої медичної (фармацевтичної) освіти: виклики сьогодення та перспективи їх вирішення : матеріали XVIII Всеукр. наук.-практ. конф. в онлайн-режимі за допомогою системи microsoft teams (Тернопіль, 20-21 трав. 2021 р.) / Терноп. нац. мед. ун-т імені І. Я. Горбачевського МОЗ України. - Тернопіль : THMУ, 2021. - C. 44-48.

3. Старченко І. І. Використання наочно-симуляційних методів навчання у викладанні патоморфології / І. І. Старченко, Н. В. Ройко, Б. М. Филенко [та ін.] // Актуальні питання вищої медичної (фармацевтичної) освіти: виклики 
сьогодення та перспективи їх вирішення : матеріали XVIII Всеукр. наук.-практ. конф. в онлайн-режимі за допомогою системи microsoft teams (Тернопіль, 20-21 трав. 2021 р.) / Терноп. нац. мед. ун-т імені І. Я. Горбачевського МОЗ України. - Тернопіль : ТНМУ, 2021. - С. 444-449.

4. Старченко І. І. Основи загальної патології / І. І. Старченко, Б. М. Филенко, Н. В. Ройко та ін. - Полтава : ПДМУ, 2021. - 102 c.

5. Роль міждисциплінарної інтеграції в сучасних умовах підготовки студентів-медиків / В. І. Шепітько, О. Д. Лисаченко, Н. В. Борута [та ін.] // Сучасна медична освіта: методологія, теорія, практика : матеріали Всеукр. навч.наук. конф. з міжнар. участю, м. Полтава, 19 березня 2020 р. - Полтава, 2020. - С. 260-261.

6. Чечотіна С. Ю. Актуальність впровадження міждисциплінарної інтеграції при вивченні фармакології / С. Ю. Чечотіна // Український стоматологічний альманах. - 2013. - № 4. - С. 86-89.

7. Міждисциплінарна інтеграція мікробіології, вірусології та імунології з попередніми і наступними навчальними дисциплінами / Н. О. Боброва, В.І.Федорченко,
О. В. Ганчо [та ін.] // Актуальні проблеми сучасної вищої медичної освіти в Україні : матеріали навч.-наук. конф. 3 міжнар. участю, м. Полтава, 21 березня 2019 р. - Полтава, 2019. - C. 20-21.

8. Методи оптимізації збереження ланцюжка спадкоємності між викладанням патоморфології та топографічної анатомії в умовах кредитно-модульної системи / S. I. Danylchenko, N. V. Royko, B. M. Filenko [et al.] // International scientific web-congress of pedagogues, psychologists and medics : materials of proceedings of the International Scientific WEB-Congress. - Prague, 2015. C. 17-21.

9. Розвиток міжпредметних зв'язків для формування клінічного мислення на основі академічних компетенцій на кафедрі патологічної анатомії з секційним курсом / Н. В. Ройко, І. І. Старченко, Б. М. Филенко [та ін.] // Актуальні питання вищої медичної (фармацевтичної) освіти : матеріали XVII Всеукр. наук.-практ. конф., м. Тернопіль, 5-6 листопада 2020 р. - Тернопіль, 2020. - С. 217-225.

Отримано 10.09.21 